https://doi.org/10.52058/2708-7530-2021-5(11)-351-357

Головач Наталія Василівна кандидат педагогічних наук, доцент, ПрАТ «ВН3 «Міжрегіональна Академія управління персоналом», вул. Фрометівська 2, м. Київ, 03039, e-mail: n_golovach@ukr.net, https://orcid.org/0000-0002-6215-6575

\title{
ФОРМУВАННЯ ЦІЛӖ ПРОФЕСІЙНОГО МАЙБУТНЬОГО У ЗДОБУВАЧІВ ЗАКЛАДІВ ВИЩОЇ ТА ПРОФЕСІЙНОЇ ОСВІТИ
}

Анотація. У статті запропонований спецкурс «Просемінар з формування цілей професійного майбутнього» для впровадження у процес фахової підготовки здобувачів останнього курсу закладів вищої та професійної освіти. Спецкурс розроблений з метою формування готовності майбутніх фахівців до планування професійного життя, розвитку компетентностей та професійно значущих якостей, їх професійного самовдосконалення. Зміст спецкурсу побудований з врахуванням проектно-орієнтованого формування у здобувачів професійних знань і вмінь відповідної функціональної приналежності, наборів професійно значущих якостей. Розроблений спецкурс спрямовує здобувачів до самостійного визначення та уточнення цілей свого професійного майбутнього, сприяє виникненню професійних інтересів та визначенню перспектив майбутнього професійного зростання, можливостей розвитку своїх компетентностей та професійно значущих якостей, визначення професійної ролі у певних моделях трудової поведінки.

Під час виконання програми спецкурсу кожний здобувач визначає власні можливості майбутнього місця роботи, оцінює ефективність прояву власних професійно значущих якостей, засвоєння знань під час виконання практичних завдань, формує практичні уміння та навички, функціональну грамотність.

Впровадження у процес професійної підготовки спецкурсу «Просемінар 3 формування цілей професійного майбутнього» визначається як фундаментальний етап шляху до самореалізації майбутніх фахівців у трудовій та інших сферах життєдіяльності впродовж всього життя, саморозвитку та самовдосконалення.

Запропонований спецкурс може бути модифікований та адаптований для будь-якої спеціальності закладів вищої та професійної освіти.

Ключові слова: формування цілей професійного майбутнього, майбутніх фахівців, спецкурс, професійного майбутнього, професійна готовність, професійні ролі, моделі трудової поведінки, закладів вищої та професійної освіти. 
Holovach Nataliia Vasylivna $\mathrm{PhD}$ (Education), associate professor, Interregional Academy of Personnel Management, Frometivska St. 2, Kyiv, 03039, e-mail: n_golovach@ukr.net, https://orcid.org/0000-0002-6215-6575

\title{
FORMATION GOALS OF THE PROFESSIONAL FUTURE TO STUDENTS OF HIGHER AND PROFESSIONAL EDUCATION STAFF
}

\begin{abstract}
The article proposes a special course «Seminar on the formation goals of the professional future» for introduction in the process of professional training of students of the fourth year of institutions of higher and vocational education. The special course is designed to prepare future specialists for professional life planning, development of competences and professionally significant qualities, their professional self-improvement. The content of the special course is constructed taking into account the design-oriented formation of students of professional knowledge and skills of the corresponding functional belongings, sets of professionally significant qualities. The developed special course directs students to self-determination and clarification of the goals of their professional future, promotes the emergence of professional interests and identifies prospects for future professional growth, opportunities for developing their competencies and professionally relevant qualities, determining the professional role in certain models of work behavior.

During the implementation of the program of a special course, each student determines their own opportunities for the future job, assesses the effectiveness of manifestation of their own professionally relevant qualities, knowledge acquisition during practical tasks, forms practical skills and skills, functional literacy.

The introduction of a special course « Seminar on the formation goals of the professional future» in the professional training process is defined as a fundamental step towards self-realization of future specialists in the labor and other spheres of life throughout life, self-development and self-improvement.

The offered special course can be modified and adapted for any specialty of institutions of higher and vocational education.

Keywords: formation goals of the professional future, future specialists, special course, professional future, professional readiness, professional roles, models of labor behavior, institutions of higher and vocational education.
\end{abstract}

Постановка проблеми. У умовах модернізації української освіти зазначається необхідність підвищення якості професійної підготовки фахівців, відповідно до соціальних та економічних потреб суспільства, запитів особистості. В останні роки проблема професійної готовності випускників закладів вищої та професійної освіти України привертає все більшу увагу сучасних науковців. Основою формування професійної готовності випускників $є$ цілеспрямований процес підготовки, який враховує ïx професійне самовизначення, власні прагнення, самопізнання щодо формування професійних цілей та завдань. Дослідження проблеми формування професійних цілей здобувачів дозволяє не тільки охопити 
теоретичні та практичні основи цього процесу, а й посилити увагу до процесу фахової підготовки в закладах вищої та професійної освіти, активізувати пізнавальну діяльність майбутніх фахівців.

Аналіз останніх досліджень та публікацій. Велику кількість наукових праць присвячено проблемі готовності особистості до певного виду професійної діяльності (М. Болдирєв, Г. Дмитренко, М. Левочко, Н. Ничкало, О. Оглобліна, В. Огнев'юк, Л. Прудка, С. Сисоєва та ін.). Водночас у наукових та навчально-методичних розробках, а також за сучасної системи освіти бракує ефективних підходів до формування цілей професійного майбутнього здобувачів закладів вищої та професійної освіти.

Мета дослідження - розробити план спецкурсу 3 формування професійних цілей професійного майбутнього у здобувачів закладів вищої та професійної освіти.

Виклад основного матеріалу. Формування професійних цілей майбутніх фахівців у процесі професійної підготовки має відбуватися відповідно до кожної з типових задач їх майбутньої професійної діяльності, що утворюють першу складову характеристики отриманих знань, умінь, навичок, рівень сформованості професійно значущих якостей особистості. При такому підході визначається інтегративний стан особистості здобувача, що поєднує його здібності, знання, уміння, навички, потреби та мотиви, його ставлення до майбутньої професійної діяльності, рівень готовності виконувати виробничі функції. Стан готовності до професійної діяльності обумовлюється багатьма чинниками, найважливішим 3 яких $\epsilon$ вже чітко визначені цілі професійного майбутнього та наявність відповідних компетенцій, певних наборів професійно значущих якостей особистості, які визначатимуть можливості їх реалізації у певних моделях трудової поведінки [1]. На думку Л. Прудкої професійна готовність залежить від сформованого рівня професійної компетентності і професійної майстерності, здатностей до саморегуляції, спрямованості до професійної діяльності, умінь мобілізувати свій духовний, особистісний та професійний потенціал щодо розв'язання поставлених завдань [2].

На нашу думку, запровадження в процес професійної підготовки запропонованої нами теоретичної моделі формування цілей професійного майбутнього у здобувачів сприятиме підвищенню рівня професійно готовності випускника, окреслить чіткі цілі та задачі щодо визначення його шляху реалізації трудового життя та кар’єрного плану.

Пропонуємо теоретичну модель формування цілей професійного майбутнього у здобувачів, яка містить такі взаємопов'язані структурні компоненти:

- спрямованість особистості до бачення свого професійного майбутнього (визначенню перспектив майбутнього професійного зростання);

- практична готовність особистості до планування професійного життя;

- готовність особистості до розвитку своїх професійно значущих якостей та компетентностей, визначення шляхів до самореалізації. 
У спецкурсі «Просемінар 3 формування цілей професійного майбутнього» нами було запропоновано зміст двох модулів, спрямованих на проектно-орієнтоване формування у здобувачів професійних знань і вмінь відповідної функціональної приналежності [4]:

Основні завдання спецкурсу полягають у формуванні:

1) цілей майбутнього професійного життя, готовності майбутнього фахівця до професійного розвитку, планування кар'єрного зростання;

2) готовності використовувати та розвивати компетентності у визначеній професійній ролі (певних моделях трудової поведінки), до професійного самовдосконалення.

3) визначення шляху самореалізації у трудовій та інших сферах життедіяльності впродовж всього життя, саморозвитку та самовдосконалення.

Було запропоновано здобувачам підготувати професійно орієнтовані роботи, самостійні розробки та презентації міні-творів. У розроблених методичних матеріалах до практичних, семінарських занять спецкурсу необхідно запропонувати здобувачам виконати презентаційні міні-твори; інструментарій та підготовлені матеріали для участі у ділових іграх та ін. [5].

Завершальним етапом реалізації формування професійних цілей майбутніх фахівців у спецкурсі здійснювалася за допомогою використання проектно-орієнтованих форм: проектування професійного профілю як особистісно-професійного автопортрету 3 наявним та бажаним рівнем професійно значущих якостей, життєвих та професійних стратегій; розробка моделей професійної діяльності (профілів) відповідно до вимог певної майбутньої посади, планів кар'єри, програм самооцінювання професійно значущих якостей (визначення наявних професійно значущих якостей 3 виявленим у себе під час діагностики рівнем та співвіднесення його до необхідного рівня якостей тієї чи іншої моделі організаційної поведінки); розробка плану самовдосконалення та професійного розвитку тощо.

За розробленими нами методичними рекомендаціями спецкурсу здобувачі виконали індивідуальний проект - «Мій кар'єрний план». Методичні рекомендації з індивідуального проекту складаються 3 ряду логічно пов'язаних між собою блоків:

Блок 1. Цінності. У цьому блоці акцентується увага на цінностях, як на найважливішому етапі, що визначає весь подальший кар'єрний план особистості. Робота $з$ цінностями не терпить поверховості. Тому здобувачам рекомендувалося задуматися над сенсом життя і цінностях. Звертається увага на тому, що цінності особистості завжди визначають іiі дії. Рекомендувалося коротко прокоментувати кожну цінність, щоб було зрозуміло, як саме здобувач розумієте кожну з них.

Блок 2. Хто я. Чим я відрізняюсь від інших. У цьому блоці наведено список питань, які допоможуть здобувачеві визначитися з власним образом. Наприклад: «Хто я такий? У чому моя індивідуальність? Для чого я прийшов в цей світ? Який я? Яким я себе уявляю? Що я за людина? За що я виступаю? У що я вірю? Які цінності та принципи (наприклад, чесність, 
взаємодопомога, самовдосконалення, кваліфікація, матеріальні цінності, задоволення, любов, спільна робота, повага інших, положення тощо) мені близькі, грають в моєму житті основну роль? Які з цих цінностей суперечать один одному і моїм сильним сторонам? В чому полягає сенс мого життя? Наскільки важливі для мене духовні та матеріальні цінності? Яке моє нинішнє становище, i куди я хочу прийти? Чому я хочу присвятити своє життя? Про яке майбутнє я мрію? Що заважає бажаному майбутньому стати реальністю? Які недоліки мого характеру не дозволяють мені подолати ці перешкоди? Що заважає мені стати тим і таким, як я хочу? Яка головна моя мета зараз? Що б мені хотілося змінити у своєму житті? Що робить мене щасливим?»

Блок 3. Мої компетентності та професійно значущуі якості. Тут пропонується здобувачеві провести аналіз та зробити висновки щодо проведеної 3 ним діагностики його компетентностей, особистісних та професійно значущих якостей. Здобувачам необхідно було розкрити у своїй роботі свої якості, які йому допомагали бути успішним у навчанні, у навчально-практичній діяльності в минулому і тепер, усвідомити свої сильні та слабкі сторони, описати їх, визначити шляхи розвитку своїх компетентностей та якостей. Здобувачам було запропоновано оформити свої результаті у вигляді таблиці swot-aнaлiзy $(S-$ сильні, $W$ - слабкі, $O$ - можливості, $T-$ загрози).

Блок 4. Моя місія. Опис місії - складна частина роботи здобувача. Усвідомлення місії можливо 3 накопиченням професійного досвіду. I щоб здобувач усвідомив свою місію до початку трудової діяльності потрібно починати з роботи над кар'єрними цілями (місія визначає кар'єрні цілі). Заява про місію має відображати життєву філософію здобувача - тобто розуміння здобувача для чого він прийшов у цей світ, чого хоче досягти i які його найважливіші бажання на шляху до самореалізації.

Блок 5. Бачення професійного майбутнього (до 60-80 років). Робота 3 візуалізацією - здобувачу пропонується уявити себе в майбутньому, наприклад, яким він себе бачить у 30 або 40 років, де працює, чим саме займається, чим наповнене життя, що принесло йому задоволення i дає відчуття якості життя.

Блок 6. Моя професійна роль сьогодні. Здобувачу пропонується розробити свій профіль враховуючи отримані результати проведеної раніше діагностики його компетентностей та професійно значущих якостей, та орієнтуючись на перелік вимог до фахівців у розрізі різних професійних ролей (певних моделях трудової поведінки), враховуючи результати проведених попередньо соціологічних досліджень, а також враховуючи інтереси, цілі професійного майбутнього самого здобувача.

На цьому етапі пропонується здобувачам оформити отримані результати діагностики у вигляді профілів (професіограм) з фіксацією динаміки кожного критерію сформованої якості. Отримані профілі кожного здобувача дають можливість наглядно побачити, які саме компетентності та набори якостей здобувачу вже зараз можна використовувати, а які необхідно далі розвивати 
та удосконалювати, 3 якої посади йому краще починати свою трудову діяльність або продовжити навчання.

Блок 7. Можливі професійні ролі в майбутньому. Цілі щзодо вдосконалення. Даний блок орієнтує здобувача на те, що у нього не тільки є можливість зробити кар'єру за рекомендованою професійною роллю і посадами. Тут здобувачу пропонується попрацювати над ключовими компетентностями, а також над якостями, які здобувач може розвинути 3 метою бачення поліваріативності своєї кар'єри або розуміння, що у нього є потенціал для цього. Звертається увага, що ключових ролей може бути кілька. Наприклад, суміщення декількох кар'єр: менеджер 3 персоналу, тренер-менеджер, фахівець 3 профорієнтації та підготовки кадрів, викладач, науковий співробітник. Професійні ролі у здобувачів можна умовно розділити на «активовані» (що вже можуть використовуватися) i «не активовані» (які будуть активно використовуватися в майбутньому) і зробити відповідні позначки поряд виконаного профілю. Під час опису своїх ключових ролей, здобувачам пропонується зосередитись на тому, що він вкладає в кожну з цих ролей, чим керується, що саме веде його до цього, і що він очікує від того, яку роль він обирає (поєднує) [5].

На індивідуальних заняттях кожен здобувач може обговорювати зроблений свій профіль 3 викладачем-консультантом для уточнення вже сформуваних професійних цілій.

Таким чином, проведена робота з розробки проекту «Мій кар'єрний план» $\epsilon$ ефективною в тому, що здобувачі самостійно можуть визначати та уточнювати цілі свого професійного майбутнього, проявляти інтерес та визначати перспективи майбутнього кар'єрного зростання, можливості розвитку своїх професійно значущих якостей, що спрямує їх на подальше навчання у магістратурі, протягом всього життя.

Висновки. Опанування здобувачами спецкурсу «Просемінар 3 формування цілей професійного майбутнього» підвищить рівень особистісно-мотиваційного ствердження у здобувачів, налаштованості їх бажання досягти успіхів та уміння долати перешкоди самоосвіту та самовиховання. Відповідно, таким станом готовності до освіти та професійної діяльності забезпечуються ії ефективність.

Перспективи подальших наукових досліджень формування цілей професійного майбутнього здобувачів закладів вищої та професійної освіти як важливої детермінанти якості підготовки сучасних фахівців полягають у грунтовному дослідженні чинників мотивації навчання здобувачів.

\section{Jimepamypa:}

1. Сакалюк О. Формування готовності менеджерів освіти до професійної діяльності в полікультурному навчальному середовищі : автореф. дис. на здобуття наук. ступеня канд. пед. наук : спец. 13.00.04 «Теорія і методика професійної освіти». Одеса, 2012. 20 с.

2. Прудка Л. Обгрунтування формування інтегративної готовності майбутніх соціальних працівників до професійної діяльності : автореф. дис. на здобуття наук. ступеня канд. пед. наук : спец. 13.00 .04 «Теорія і методика професійної освіти». К., 


\section{3. $24 \mathrm{c}$.}

3. Новий український тлумачний словник: близько 20000 слів і словосполучень / [укл. Н. Д. Кусайкіна, Ю. С. Цибульник ; за заг. ред. В.В.Дубчинського]. Х.: Клуб сімейного дозвілля, 2008. 608 с.

4. Головач Н. В. Методичні рекомендації щодо забезпечення самостійної роботи здобувачів 3 дисципліни «Просемінар 3 економіки та управління персоналом» (для бакалаврів). К.: МАУП, 2016. 24 с.

5. Головач Н. В. Формування професійно значущих якостей майбутніх фахівців 3 управління персоналом та економіки праці у процесі фахової підготовки : дис. ... канд. пед. наук : 13.00.04 / Нац. пед. ун-т ім. М. П. Драгоманова. Київ, 2017. 233 с.

\section{References:}

1. Sakalyuk O. (2012) Formuvannya gotovnosti menedzheriv osvity` do profesijnoyi diyal`nosti $\mathrm{v}$ polikul turnomu navchal`nomu seredovy`shhi [Developing education managers' readiness for professional activity in the policultural educational environment] Avtoref. dy`s. na zdobuttya nauk. stupenya kand. ped. nauk : specz. 13.00.04 «Teoriya i metody`ka profesijnoyi osvity`». - Odesa. [in Ukrainian].

2. Prudka L. (2013) Obg`runtuvannya formuvannya integraty`vnoyi gotovnosti majbutnix social`ny`x pracivny`kiv do profesijnoyi diyal`nosti [Substantiation of formation integrative readiness of future social workers for professional activity] Avtoref. dy`s. na zdobuttya nauk. stupenya kand. ped. nauk : specz. 13.00.04 «Teoriya i metody`ka profesijnoyi osvity`»]. Kyiv. [in Ukrainian].

3. Novy`j ukrayins`ky’j tlumachny`j slovny`k: bly`z`ko 20000 sliv i slovospoluchen`. (2008) [New Ukrainian explanatory dictionary] Ukl. N. D. Kusajkina, Yu. S. Cy`bul`ny`k ; za zag. red. V. V. Dubchy`ns`kogo. X.: Klub simejnogo dozvillya. [in Ukrainian].

4. Golovach N. V. (2016) Metody`chni rekomendaciyi shhodo zabezpechennya samostijnoyi roboty` studentiv z dy`scy`pliny` «Proseminar z ekonomiky` ta upravlinnya personalom» [Proseminar on economics and personnel management] Kyiv. [in Ukrainian].

5. Golovach N. V. Formuvannya profesijno znachushhy`x yakostej majbutnix faxivciv z upravlinnya personalom ta ekonomiky' praci u procesi faxovoyi pidgotovky` [Formation of professionally important qualities of future specialists in the field of personnel management and labour economics during the professional education process] Dy`s. ... kand. ped. nauk : 13.00 .04 / Nacz. ped. un-t im. M. P. Dragomanova. Kyiv. [in Ukrainian]. 